\title{
Audit Committees: The Journey So Far In Nigeria
}

\author{
Atu,Omimi-Ejoor Osaretin Kingsley \\ (Aca,Fcma,Acti,Aat, M.Sc(Accounting), M.Sc(Business), Mba(Accounting)Pdg (Comp.Sc); Dipl.Ph.D In View) \\ Lecturer - Department Of Accounting Igbinedion University, Okada. Edo State, Nigeria-West Africa.
}

\begin{abstract}
Before 1989, there was no issues of audit committee in Nigeria. In 1989 Professor Olowokure article titled a Case for Audit Committee in Nigeria was written drawing the attention of Government, Stakeholders for the use of Audit Committee in public companies in Nigeria. Hence this was captured in the CAMA 1990 as amended Section 359 (3), it then become very important in Nigeria. The importance have led to problematic issues which resulted to why the research is been carried out.
\end{abstract}

Keywords: Corporate Governance, Audit Committee, Board of Directors, shareholders.

\section{Introduction}

Over the years, Financial Statement has grown considerably in size and importance following the rapidly changing Socio-Political and Economic Environment. Such Statement include, among others, the Balance Sheet, Profit and Loss Account, Value Added Statement, Cash-Flow Statement, Five-year Financial Summary etc; and they are prepared and presented in accordance with Generally Accepted Principles, rules, procedures etc which apply globally (Obi 1996).

However, the modern day Financial Statements, that is the IFRS Financial Statements comprise of a Statement of Financial Position, a Statement of Comprehensive Income, a Statement of Changes in Equity, a Statement of Cash Flows and Notes to the Financial Statements. (Steve, 2012)

In preparing such Financial Statements, companies are also bound by the statutory rules and regulations applicable in the respective countries in which they operate. Prior to Companies and Allied Matters Acts, 1990 as amended, there were no statutory provisions for the compulsory Audit of a company's Financial Statements. As many companies, realizing the necessity for protecting the interest of the investing public, they inserted a clause in their Article of Association, for the preparation of Annual Audit by an independent persons. In the light of this Auditing as cited in Atu, (2010) is;

"The independent critical examination of and an expression of opinion on, the Financial Statements and underlying records of an enterprise by an appointed Auditor. In pursuance of the Audit objective, the preparation of the financial statements is the responsibility of the management. The responsibility of the auditor is to report on the financial statement as presented by the management"

The Accounting Profession in Nigeria has been under intense pressure due to rising public expectations. The rise in public expectations was occasioned by the series of financial failure that occurred during the recessionary years of late 80's and early 90's. (Atu, 2010). In the light of the situation, Government, Stock Securities Operators and corporate managers devised a way of reducing financial failure in order for the public and other users to have confidence in corporate financial reporting. This has lead to the establishment of Audit Committee which enable Directors to increase their efforts in attending to other matters while assigning specific issues to the Audit Committees.

During the 1970 to 1978, the role of Audit Committee received much attention because of the demands for Greater Corporate Accountability and Probity.

In Nigeria, as cited in (Atu, 2010) Professor Olowokure of the University of Maiduguri, (1989) published a twopage article in The Nigeria Accountants Titled A Case for Audit Committees in Nigeria, for the need to set up Audit Committees for publicly quoted companies in Nigeria as a means of restoring the Credibility of Financial Reporting.

Today, all over the world publicly traded companies maintain Audit committee. In Nigeria this was provided for in Section 359(3) CAMA (2004) (as amended) for External Auditors to report to an Audit Committee.

It's noted that Audit committee, were originally conceived as a means of ensuring the independence and effectiveness of External Auditors. It has been defined as a Committee of Directors of a Company whose specific responsibility is to review the Annual Financial Statements before submission to the Board of Directors.

\section{THE NATURE OF AUDIT COMMITTEES IN NIGERIA}

Section 359(3) of the CAMA (2004) as amended provides for the establishment of Audit Committees in public Companies in Nigeria thus: "The auditor shall in the case of a Public Company also make a report to 
an Audit Committee which shall be established by the Public Company."This provision was further fortified by Section 359(4) which provides that the membership of the committee shall be composed of equal number of directors and shareholders' representatives so that the maximum number of members of the committee shall not exceed six. The provision on the establishment of Audit Committees in Public Companies in Nigeria was further boosted in 2003 by the Code of Best Practices of Corporate Governance in Nigeria, issued by the Securities and Exchange Commission, which was applicable to all public companies in Nigeria. According to (Nat, 2013) the 2003 SEC Code enjoined companies to have Audit Committees and further indicated directors' representatives in the Audit Committee. The 2003 SEC Code has now been replaced by the Code of Corporate Governance in Nigeria 2011 issued by the Securities and Exchange Commission and which became effective on 1st April 2011. Perhaps, taking a clue from the provisions of the 2003 SEC Code, the Code of Corporate Governance for Banks in Nigeria Post-Consolidation, issued by the Central Bank of Nigeria and mandatory for all banks operating in Nigeria also made provision for the establishment of audit committees in all banks operating in Nigeria. Furthermore, the Code of Corporate Governance for Insurance Companies in Nigeria issued by the regulator of the Insurance Industry in Nigeria, National Insurance Commission (NAICOM), similarly provided for the establishment of Audit Committees in Insurance and Re-insurance companies operating in Nigeria. However, in the Code of Corporate Governance for Licensed Pension Operators issued by the National Pension Commission (PENCOM), the Audit Committee only received a mere mention in two provisions; the first provision, recognizes the Audit Committee as one of the Committees the Board of Directors of a relevant company can establish to facilitate its work and the second provision stipulates that the Corporate Governance report to be prepared by a relevant company for submission to PENCOM should contain the composition of the Audit Committee of the company and the details of the Committee's activities. (Nat, 2013)

\section{FUNCTIONS OF AUDIT COMMITTEES.}

The Statutory functions of Audit Committees are as stipulated in Section 359(6) of the CAMA (2004) as amended provides as follows:

"Subject to such other additional functions and powers that the company's articles of association may stipulate, the objectives and functions of the audit committee shall be to:

- Ascertain whether the accounting and reporting policies of the company are in accordance with legal requirements and agreed ethical practices;

- Review the scope and planning of audit requirements.

- Review the findings on management matters in conjunction with the external auditor and departmental responses thereon;

- Keep under review the effectiveness of the company's system of accounting and internal control;

- Make recommendations to the Board in regard to the appointment, removal and remuneration of the external auditors of the company; and

- Authorize the internal auditor to carry out investigations into any activities of the company which may be of interest or concern to the committee."

Others are, According to (Atu, 2010):

- Review, releases, other information of news media, general public, and stockholders with respect to the Financial condition of a Company and approve or disapprove such dissemination;

- Approve or disapprove any change of Company Independent directors

- Review the result of the Independent Auditor examination of the Financial Statements;

- Review all transactions by the directors in the shares of the company and all transactions with related parties;

- Review directors' remuneration and pension arrangement.

The CAMA 2004 as amended in Section 359(4) also authorizes the Audit Committee to "examine the auditors' report and make recommendations thereon to the Annual General Meeting as it may think fit."

According to (Nat, 2013) the above Statutory Provisions are complemented by the provisions in some Corporate Governance Codes. Admittedly, some of the functions of the audit committee stated in the corporate governance codes are a recast of extant statutory provisions. Generally, the functions of the audit committee as stipulated in corporate governance codes for banks include assisting in the oversight of the integrity of the company's financial statements, review the terms of engagement and recommend the appointment or re-appointment and compensation of external auditors to the Board and the shareholders, risk assessment and management, ensure the development of a comprehensive internal control framework for the company, review and ensure that adequate whistle-blowing procedures are in place, and monitoring of corrections by which enjoins the Board or Board Risk Management Committee to establish policies on risk oversight and management which requires the Internal Auditor to report directly to the chairman of the Audit Committee but forward a copy of the report to the MD/CEO of the Bank which merely compels Banks to have a whistle-blowing procedure in place. 


\section{LIMITATIONS IN AUDIT COMMITTEES}

The problems of the concept of Audit Committee in Nigeria Public Companies as cited in Atu, (2010) are stated below:

- The Committee lack management support.

- It was establish just to satisfy the letters of the Companies Decree;

- Lack of motivation, CAMA 2004 as amended provides that a member of the Audit committee shall not be entitled to remuneration and shall be subject to re-election;

- $\quad$ Audit Committee is a talking workshop of Directors;

- Causes conflict between External Auditors and the Management;

- The Members lack Accounting and Financial Reporting knowledge.

- The composition as stated in Companies and Allied Matters Act 2004 as amended Sections 359 (4), provides, that the composition shall consist of an equal member of Director and Representative of the Shareholders of the Company. This can easily lead to lobby of either side voting for the other for a decision to be reached;

- $\quad$ Lack of effective meeting of the members.

- The meetings of the Audit Committees in most companies are rather routine and not sufficiently scrutinizing. This conclusion is underscored by the fact that the reports issued by some audit committees over the years have consistently remained exactly the same, year on year.

Others are:

- Issues of multiple Directorships (Atu, 2013).

- The CAMA 2004 as amended which is the Act regulatory business operations in Nigeria did not specify the problem of financially literacy for members of audit committee.

- Management not having the trust to disclose crucial corporate matters in meetings where Audit Committee members are present.

- Establishment of parallel Audit Committee to undertake the functions of audit committee to consider matters too crucial and sensitive to be exposed to shareholders representative.

- Absence of statutory provision concerning Professional Qualification for members of Audit committee

- Companies treating audit committee with trivial trust, reduced responsibilities and reluctant respect.

- Lack of adequate time for Audit Committee members discharge their responsibilities

\section{Conclusion/Recommendations}

After 20 years of the existence of audit committees in corporate administrative structure in Nigeria, it is arguable whether audit committees have merited good cheers for any meaningful contributions to their respective organizations. It is doubtful if it can be asserted with confident assurance that the impact of audit committees has been huge, positive and commendable. In terms of corporate administration, audit committees have carried themselves like an unnecessary burden imposed on companies. Certainly, the management of most companies do not trust the audit committees enough to disclose crucial corporate matters at their meetings. Thus, Nat (2013) noted that companies have continued to tag along with audit committee simply because they are a creation of law, not necessary because they are seen to be value adding or helpful in the management of the companies. The principal factor responsible for this negative state of affairs concerning audit committees is the composition of the committees. Another negative aspect of the membership of audit committee relates to the absence of statutory provisions concerning the professional qualification for members of Audit Committees. Some of the Corporate Governance Codes have tried to fill this lacuna in the CAMA (2004) by providing that members should have basic financial literacy with at least one member being a financial expert, and empowering Audit Committees to seek outside Professional assistance if they require same in the course of their assignment, This was however not reflected in CAMA 2004 as amended. Furthermore, Audit Committee lack adequate time, in the discharge of their responsibilities. If Audit Committees are to truly and fully carry out their functions as stipulated in the CAMA (2004) and Several Corporate Governance Codes, it will make members of Audit Committee to be very busy. But poor membership and cringing tendencies have made members of audit committees not to be alive to their responsibilities. Consequently, over two decades after the establishment of audit committees in Nigerian public companies, the only real beneficiaries are those shareholders who have had the opportunity to be members of the Audit Committees composition as that has granted them the privilege of one-on-one rapport with the management of their companies. There is, therefore, an urgent need to rethink the structure of audit committees in Nigeria if the committees are to deliver the essential corporate governance benefits that necessitated their introduction into the corporate administrative structure of public companies. Needless to say that the regulators, especially the Securities and Exchange Commission, have enormous responsibility to ensure the realization of this fundamental paradigm shift 
To be able to overcome the problematic issues of audit committee in Nigeria, the following recommendations if adopted will be of immense benefits to Government, Public and Private Companies, Parties interested in Accounting information, etc.

- The composition of audit committee should be changed from the present six members to five members as it is obtained in other part of Western Countries.

- Nigerian Banks should tap from USA experience in areas of quality control, Audit Committee composition, Qualifications, meetings of audit committee members as regards numbers of times they should hold meetings in a year e.g. 6-10 times per year, either face to face or via teleconferencing;

- Organizational politics in aspect of audit committee appointment should be reduced to bearest minimum. In addition, the chaired person must have experience as a CFO, external auditor, or CEO'

- Audit Committees should pay more attention to the Goings- on in the Internal Audit Departments to ensure their complete Independence, Risk Management, Internal Control and Accounting estimates;

- Financial Statements should be made ready as quickly as possible;

- Company and its Board of Directors must show full commitment to corporate accountability by providing conducive environment in which their audit committee can discharge its responsibilities efficiently and effectively;

- Management should not restrict the scope of the audit committee inquiry;

- The meetings of audit committee should at least be a give and take exercise where problematic issues can be discuss.

- The external auditor must strive to ensure that he discharges his duties objectively, professionally and ethically in order to sustain the confidence reposed in him by users of his services;

- Other regulatory bodies like NASB (Nigeria Accounting standard Board) now FRC (Financial Reporting Council of Nigeria) should strive to review regularly the principles in use in line with economic needs and developments in the business world. The local GAAP and IFRS are dynamic concepts which requires constant review, adaptations and reaction to changing circumstances;

- There should be proper law to ensure that management of companies have no influence in the election and in determining the allowance of the audit committee members;

- Majority of audit committee members should come from the shareholders rather than from the directors.

- Members of Audit Committee are to be trained with the new Era (IFRS) in the way accounts or financial reporting is been prepared now.

- $\quad$ Adequate time should be provided for members to effectively discharge their responsibilities.

\section{References}

[1]. Atu, Omimi-Ejoor O.K., (2010), The Role of Audit Committee in Financial Reporting (A Case study of First Bank Plc). An M.Sc Research Work Submitted to the Department of Accounting, Igbinedion University, Okada.- Nigeria.

[2]. Atu, O.O.K,\& Atu, E.R (2010) Auditing: The Journey so Far and It Expectation Gap. The Official Journal of The Institute of Chartered Accountants of Nigeria. April/ June 43 (2) 46-52 Lagos-Nigeria

[3]. Atu, et.al (2013), The Role of Audit Committee in Enhancing Financial Reporting In Nigeria IOSR Journal of Business and Management, September -October 2013 13(1) 27-34 www.iosrjournals.org. India.

[4]. Babalola, Y.A. (2013), Corporate Audit Committee and Risk Controlling in Nigeria. European Journal of Business and Management .5(12). Retrieved at www.iiste.org on 23/8/2013.

[5]. Companies and Allied Matters Act, CAMA (2004) as amended. Abuja -Nigeria

[6]. Carcello, J \& Neal T. (2000) Audit Committee Composition and Auditor Reporting. Accounting Review, 75 (4)

[7]. Daniel A. N, (1990) "Companies Decree 1990 and the Auditors attestation" The Nigerian Accountants: The Official Journal of The Institute of Chartered Accountants of Nigeria. April/ June 23(2) 24-28 Lagos-Nigeria

[8]. http://en.wikipedia.org/wiki/audit_committee (Accessed 20/8/2013)

[9]. Innocent O, (1998) "Questions and Answers on Nigerian and International Accounting Standards" Arnold Consulting Limited Nigeria.

[10]. Institute of Chartered Accountant of Nigeria, Study Pack (2006): "Financial Reporting and Audit Practice" (VI_Publishing Limited Lagos- Nigeria).

[11]. Institute of Chartered Accountant of Nigeria, Study Pack (2010), Advanced Audit.and Assurance Professional Examination 1, VI Publishing Limited, Lagos - Nigeria

[12]. Nat Ofo, (2013) "An Appraisal of Audit committees of Public Companies in Nigeria". Available online at: http://ssrn.com/abstract=1641603 (Accessed on 20/08/2013)

[13]. Obi A., (1996) "Financial Statements Still a Long Way to Go". The Official Journal of The Institute of Chartered Accountants of Nigeria. April/June, 29(2) 1-6 Lagos-Nigeria

[14]. Olowokure, (1989), A Case for Audit Committee in Nigeria. .The Official Journal Of The Institute of Chartered Accountants of Nigeria. Lagos-Nigeria

[15]. Okolo J.U.T., (1989) "Management Audit", Ambik Press, Limited. Benin City, Nigeria.

[16]. Steve C. (2012), IFRS for Dummies, John Wiley's \& Sons Limited, Publication West Sussex, England.

[17]. Tom L, (1982) “Company Auditing”, (Edinburg Gee \& Company Publisher Limited, Scotland). 